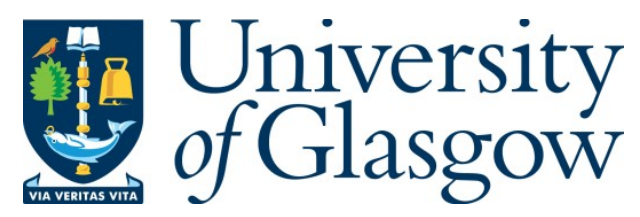

Murphy, M. (2020) Public sector accountability and the contradictions of the regulatory state. Administrative Theory and Praxis, 42(4), pp. 517-530.

(doi: $\underline{10.1080 / 10841806.2019 .1700455)}$

This is the Author Accepted Manuscript.

There may be differences between this version and the published version. You are advised to consult the publisher's version if you wish to cite from it.

https://eprints.gla.ac.uk/204470/

Deposited on: 3 December 2019

Enlighten - Research publications by members of the University of Glasgow http://eprints.gla.ac.uk 


\title{
Public sector accountability and the contradictions of the regulatory state
}

\author{
Mark Murphy, University of Glasgow
}

\begin{abstract}
A substantial amount of research evidence has been gathered regarding the pathologies of accountability, but less attention has been paid to the reasons why such pathologies occur in the first place. The paper addresses this issue by exploring accountability in the context of Habermas' theory of lifeworld colonization. The paper explores the value of the colonization thesis to modern day issues associated with the "regulatory state", that form of state governance with surveillance and enforcement strategies at its core. It takes seriously the contribution that Habermas can make to the field of public administration - a contribution that can position the field in its broader context of democratic governance. At the same time, it is accepted that there are limitations of the colonization thesis as an explanatory device, with the paper arguing that not all the consequences of accountability can be considered illustrative of a damaged communicative intersubjectivity. Specifically the paper turns to the concept of street-level bureaucracy for further refinement of Habermas' ideas around governance.
\end{abstract}

\section{Introduction}

In his classic text, Street-level bureaucracy (1980), Michael Lipsky argued that accountability in public service and political life is necessary and legitimate, as it served as the link between 
bureaucracy and democracy (Lipsky, 1980, p. 160). Decades on from this statement, however, the evidence for such a link is increasingly tenuous. There has amassed a large body of research that suggests that accountability is often a weak link in the state armoury and can create more problems than it solves. Far from acting as an honest broker between bureaucracy and democracy, the accountability agenda has resulted in sets of "perverse effects" (De Bruijn, \& Van Helden, 2006, p. 406) including the "loss of professionalism", increased time pressure on time-poor professionals (Franco-Santos et al, 2012, p. 42) and damage to their capacity to engage with the public (Murphy and Skillen, 2015). Quality assurance mechanisms such as performance indicators are blamed for introducing "corrosive" practices into the university sector (Schwier, 2012; Shore, 2008), and in some cases for having the opposite effect to that for which they are intended (West, 2010). More than anything, accountability has been blamed for encouraging institutional regimes of "symbolic compliance and impression management" (Visser, 2016, p. 79), leading to what Hood calls sets of "assurance behaviours" (Hood, 2011, p. 127) - behaviours that can be used by organisations and individuals "in their efforts to fend off blame" (Hood, 2011, p. 129).

While the evidence has stacked up regarding the pathologies of accountability, less attention has been paid to the reasons why such consequences occur in the first place. This paper addresses this issue by exploring these pathologies via Jürgen Habermas and his theory of lifeworld colonization $(1984,1987)$. Briefly put, this theory suggests that the negative consequences of modernization, ushered in by a one-sided process of (instrumental) rationalization, manifest themselves in distorted relations that valorise measurable outcomes over the process of mutual understanding and communicative reason. Effectively, for Habermas, bureaucratic mechanisms of accountability are "tricky" (Barberis, 1998, p. 451) 
because they have a tendency to overstep their limits, the red tape of political bureaucracy stifling the imperatives of an intersubjective world in which its remit does not govern.

The paper explores the value of this colonization thesis to modern day issues associated with the "regulatory state", that form of state governance with surveillance and enforcement strategies at its core (Majone, 1997; Moran, 2007; Glaeser \& Shleifer, 2003). Specifically, the paper will explore Habermas' potential contribution to debates over the consequences of the regulatory state in the guise of accountability regimes, consequences that have previously tended to focus on issues such as impression management and risk avoidance without necessarily situating these consequences in a broader theory of societal change. Habermas' theory of colonization is well placed to provide such a theory of societal change and this theory is used in this paper to detail one set of consequences around what I call 'distorted relations'. The focus on relations in the regulatory state illustrates the damage such an approach to governance inflicts on what Habermas called 'communicative' rationality.

At the same time, it is accepted that there are limitations of the colonization thesis as an explanatory device, with the paper arguing that not all the consequences of accountability can be considered illustrative of a damaged communicative intersubjectivity. Specifically the paper turns to the concept of street-level bureaucracy for further refinement of Habermas' ideas around governance and its relevance to theories of the regulatory state.

\section{The problem of bureaucracy in the regulatory state}

The tension between democracy and bureaucratic governance has long been a focus of attention of academics in political science and economics, but it is the field of public administration that 
provides this focus with its normative core (Meier \& O'Toole, 2006). This is a field heavily influenced by the work of Max Weber (1968), who viewed bureaucracy as a necessary component of any modern democracy. Bureaucracy for Weber underpinned a strong state (a condition he was much in favour of, particularly as regards Germany at the time), as well as providing a viable structure for the spread of modern capitalism. The rationality of efficiency and organisation offered by bureaucratic modes of government ensured that the potential for economic and social progress is maximised. The characteristics of bureaucracy such as office hierarchy, rigid rules and norms, precision, accuracy, clarity - these all made vital contributions to the hyper efficiency required in $20^{\text {th }}$ century political and economic life.

Such progress, however, comes at a cost, and that cost can be especially detrimental to institutional and professional autonomy. Weber once famously remarked that bureaucracies "can serve any master" (1946), meaning that bureaucracy could be used to control and dominate or alternatively it could be used to liberate, depending on who is in power. With bureaucratic administration comes domination - "every domination expresses itself and functions though administration. Every administration, on the other hand, need domination, because it is always necessary that some powers of command be in the hands of somebody" (Weber, 1954, p. 109).

When it came to assessing the efficacy of bureaucracy, Weber was caught in a bind: he valued and saw the need for systems of formal rationality i.e., for characteristics such as calculability, predictability, efficiency, control, and their institutionalisation in bureaucratic modes of governance. These he saw as essential to managing the complexity of modern societies. Weber considered formal rationality as "superior to any other form in precision, in stability, in the stringency of its discipline and in its reliability" (Weber, 1968, p. 337). But he also saw this as 
the curse of modernity - the valorisation of efficiency and calculability sucked much of the freedom and meaning out of social life and left society in what he poetically referred to as the "polar night of icy darkness" (Weber, 2001, p. 123). This led him to characterise rationalisation more broadly as an "iron cage".

Much of the public administration literature has tended to focus on this domination tendency of bureaucracy, in which bureaucratic procedures and system are "considered a conspiracy against the public" (Meier \& O'Toole, 2006, p. 7). In the eyes of these critics, bureaucracy is "synonymous with inefficient business administration, pettifogging legalism, and red tape" (Clegg, 2011, p. 207). This is also the case for what Travers (2007) calls the new bureaucracy of quality assurance, the mechanisms of accountability that have mushroomed in the era of the regulatory state. The research on accountability suggests that the iron cage of Weber's nightmares has descended once again via the proliferation of auditing, evaluations, inspections and performance indicators (Diefenbach, 2009; Papadopoulos, 2010).

While such critiques highlight some of the downsides of modern forms of bureaucracy, little if any discussion has occurred that has encompassed a revisiting of Weber's dilemma in the context of accountability regimes. Instead, the academic literature has devoted its energies to describing and classifying the workings of the regulatory state, particularly in the shape of new public management (Christenensen, Lie \& Laegeid, 2007). While such analyses have their uses in debates over accountability, they would benefit from a more socio-theoretical approach to the topic of governance. Given the way in which Habermas has reconstructed Weber's approach to modernity and bureaucracy, his conceptual apparatus is an obvious choice for the task. 


\section{From labour commodification to lifeworld colonization}

Habermas' conception of bureaucratic governance reflects his intellectual lineage, not only that of Weber but also the roots of the Frankfurt School in the theories of Karl Marx. Marx's critical approach to social analysis aimed to identify the pathologies generated by capitalist modernization, an approach adopted by the Frankfurt School in their efforts to develop a critical theory of society. Two key pathologies identified by Marx were alienation and commodification (Marx, 1959). Theodor Adorno and Max Horkheimer, key figures in the work of the early Frankfurt School, developed their own pathology in the shape of the "totally administered society" (1973) - an idea of an over-bearing reason that combined the worst effects of alienation, commodification as well as Weber's iron cage.

Habermas appropriated aspects of these analyses for his own work, but his analysis of the dysfunctions of capitalist modernisation manages to both update and also transform conceptions of capitalism and state governance. In devising his own conceptual apparatus Habermas tended not to engage with the dominant Marxist critiques of the state that were fashionable at the time. When he was developing these ideas, in the 1960s and 1970s, debates over the capitalist nature of the state were dominant in the critical sociology and political science literature. Marxist theorists such as Ralph Miliband and Nikos Poulantzas were prominent in these debates, seeking sophisticated analyses of the relation between the state and market - echoes of these analyse can still be found in contemporary Marxist political economy, a field that devotes much of its energy to assessing the impact of multinational corporation on nation state forms of democracy (Jessop, 2015). 
While Habermas shared with Marx a concern over the unjust distribution effects of capitalism (Müller Doohm, 2010, p. 449), he was also concerned to avoid what he considered to be a form of analytical conflation when it came to the state-economy nexus. Habermas' conceptual aim was to ensure that the political and economic realms retained their unique and distinct character while also crafting theoretical space for action-oriented approaches to political economy. To assist his aim, he developed a theory of steering media (a term he appropriated from other theorists, especially Niklass Luhmann), key amongst which were power and money. The introduction of this robust functionalist element allowed Habermas to deliver a reconstructed Marxist historical materialism which provide him with a welcome escape route away from deterministic approaches to theory.

This reconfiguration also helped Habermas in its efforts to grapple with $20^{\text {th }}$ century problems of public administration. This was especially true in his analysis of the welfare state compromise, an analysis developed with one of the key Marxist questions in mind: how did the capitalist system manage to avoid a working class revolution? As a partial response to this question, Habermas suggests that the welfare state compromise, one aimed at managing capitalist exploitation while alleviating its worst effects, went some way to quelling revolutionary favour among the working class. At the same, he envisaged significant problems with this compromise when it comes to the legitimacy of the state to govern. In his book Legitimation crisis (1976), Habermas theorises that legitimation crises result from nation states overstepping their limits. The greater responsibility states adopt over welfare services as well as consumption, the more likely it is that crises of social integration will take place in the lifeworld. As a result the state, if it cannot somehow adequately confront the pathologies of capitalist modernization, it ends up paying a price, and the "price for this failure is withdrawal of legitimation" (Habermas, 1976, p. 69). 
The lifeworld, part of Habermas' new two-level conception of society, was the site of this legitimation withdrawal. This conception afforded Habermas the opportunity to deliver an action-theoretic as well as a systems-theoretic analysis of the process of societal rationalisation. He uses the term lifeworld to signify the background consensus of everyday lives, which includes the taken-for-granted understandings of social life that guide people's lives, while the system refers to the world in which political and market imperatives dominate; i.e., the state administrative apparatus (steered by power) and the economy (steered by money). This twolevel concept of society provides Habermas with the tools to examine the increasing autonomy of what he calls "systematically integrated action contexts" from socially integrated lifeworlds (1987, p. 305).

This dual-perspective methodological reconstruction provided Habermas with the framework to tackle the core issue at the heart of Weber's theory - bureaucratization and the iron cage of modern public administration. While Habermas relies heavily on Weber's analysis of societal rationalisation and its troubling side-effects $(1987$, p. 301), at the same time he takes Weber to task for equating capitalist modernisation to societal rationalisation. Key to this critique is the fact that Weber's take on the iron cage was guided by the restricted idea of purposive rationality.

According to Habermas, Weber's reliance on the model of the purposive-rational actor leads Weber to provide an inaccurate diagnosis of the times. In order to present what Habermas considers to be a more effective diagnosis, it is necessary to provide a substantial restructuring of Weber's theory. This re-structuring was based on two grounds: first, Weber emphasised the idea of purposive rationality to the exclusion of other forms of rationality; and second, he 
confused action theoretic and system theoretic concepts. To counter the first problem, Habermas proposes the introduction of the concept of communicative rationality 'tailored to the lifeworld concept of society and to the developmental perspective of lifeworld structures' (Habermas 1987, 305).

The second problem was resolved by Habermas via his two-level concept of society - system and lifeworld; this offered an analysis of the process of societal rationalisation via both an action-theoretic and a systems-theoretic perspective. This dual perspective offered up a wholly new way of understanding bureaucratization: While for Weber, bureaucratization represented the institutionalisation of purposive-rational action, Habermas argued that bureaucratization "should be regarded as the sign of a new level of system differentiation" (1987, p. 307). Bureaucratization for Habermas was the anchoring of the steering mechanisms of the economy and the state - money and power, respectively - in the structures of the lifeworld.

Habermas reconfigured this bureaucratization thesis in terms of a conflict between social and system integration, a distinction that highlighted the co-existence of two sets of relationships, one between actors and one between parts of the system. The conflict between these sets of integrative relations has implications for state governance and its effects on lifeworld contexts. It means, because sets of actions are no longer socially integrated, but rather take their cues from the system, social relations become divorced from actor's identities. Increasing bureaucratisation has resulted in a heightened separation between social relations and the identities of actors in the lifeworld (Habermas, 1987, p. 311).

Weber understood the trend towards bureaucratisation in action-theoretic terms. For him, the paradox of societal rationality lay in the relations between two different types of action 
orientations; that is, value-rational action and purposive-rational action orientations. Habermas, however, argues that bureaucratisation and the paradoxes that arise from it should instead be understood in terms of a relation between two different types of societal integration, namely social and system integration.

Phenomena related to the iron cage now count as "effects of the uncoupling of system and lifeworld" (Habermas 1987, p. 318). As the media of money and power function independently of language, they are not connected to the communicative structures of the lifeworld, which are dependent on language as the means of reaching understanding. As a consequence, these media allow the uncoupling of formally organised domains of action from the structures of the lifeworld, which in turn unleash their functionalist reason of system maintenance onto the lifeworld structures. It is this pathological side-effect of societal rationalisation that Habermas refers to as the "colonization of the lifeworld".

Alongside this analysis, Habermas takes care to emphasise the role of bureaucratization as an ordinary and to some extent legitimate component of modernization processes. (1987, p. 318) He thus makes a distinction between functional and dysfunctional forms of bureaucratization, as he needs to distinguish the normal mediatisation of the lifeworld from the pathological colonization of the lifeworld. For Habermas, it is only when the economic and political system, via the media of money and power, attempt to reify the symbolic structures of the lifeworld that pathologies occur. Only actions that align well with economic and political imperatives can be adopted by the steering media of money and power. These media, however, are out of place - dysfunctional - in areas such as cultural reproduction, social integration, and socialisation - the work of the lifeworld. Imperatives associated with money and power cannot 
transplant themselves onto these forms of symbolic reproduction with "without pathological side-effects" (Habermas, 1987, pp. 322-323).

It is this "systematically induced reification" (Habermas, 1987, p. 327) of the symbolic structures of the lifeworld that Habermas views as constituting colonization - his "malignancy thesis" as White calls it (2016, p. 195). The capacity to act communicatively and to fulfil the symbolic reproductive function of the lifeworld is under threat from systemic imperatives, which, via the media of money and power, reify those structures of the lifeworld that are based on communicative action. Habermas (1987, p. 326) terms this reification of everyday communicative practice a "one-sided rationalisation", a restricted rationality ushered in by the process of capitalist modernization, a process with origins in "the growing autonomy of mediasteered subsystems, which not only get objectified into a norm-free sociality beyond the horizon of the lifeworld, but whose imperatives also penetrate into the core domains of the lifeworld" (1987, p. 327).

\section{Relational distortion and the regulatory state}

With this reformulated scenario one can start to put together a different, more nuanced take on bureaucracy. Now political regulation in the form of accountability mechanisms can now be assessed from two different angles - one in which the instrumental rationality of efficiency and cost-effectiveness must take up space alongside the capacity of this form of steering to offer communicative value. The value of transparency and surveillance as a form of public answerability must be judged alongside its capacity to overshadow and damage forms of intersubjective communication - orientations to mutual understanding as opposed to meansend calculations. 
Applying this thesis of a one-sided rationality run amok to the field of public sector regulation, one can start to make claims as to its relevance - does evidence of colonization exist? Where do dysfunctional forms of bureaucracy manifest themselves? An appropriate area to highlight in this regard is the intersubjective communicative aspects of the public sector - the manner in which these damaging effects get played out in the key relations across fields such as health, education and social work. More specifically, this would entail a study of the relations between professionals and end users - for example relations between teacher and student, doctor/nurse and patient, and social worker and client.

One study that engages with this type of front line relations is that of Steijn and van der Voet (2017), as part of their focus on the job satisfaction of public sector workers. Their research suggest that public sector professionals are more sensitive to burdensome rules and procedures, due to the fact that the red tape of accountability acts "as a hindrance stressor that thwarts the realization of prosocial aspirations" (Steijn \& van der Voet, 2017, p .1). The stress of surveillance and compliance measures has resulted in a set of negative effects on their interactions with the public. Because of the red tape of accountability, employees "devote less time to their clients and have less opportunity to have an impact on their lives" (Steijn \& van der Voet, 2017, p .12). Distorted relations in this case relate to the impact of red tape on both to the quality and quantity of interactions with their clients.

Viewed through the prism of the colonisation thesis, these findings can be understood as the result of an over-bearing instrumental reason narrowing the space and opportunity for communicative practices to emerge. Such a take on relational distortion as a consequence of colonisation is a plausible one, and one that has already been discussed by researchers keen to 
put Habermas to work in applied professional settings (Murphy, 2017). A key point of reference for this approach is Blaug's notion of the "distortion of the face to face" in relation to social work practice (Blaug, 1995). Social work for Blaug is a "dual aspect" activity, as it by necessity combines instrumental with communicative rationality (1995, p. 427). But the increasing bureaucratization of social work had resulted in an imbalanced agenda, as it has embedded the "systematic colonization of communicative practices by instrumentalism". He illustrates this form of colonization using the example of casework supervision, which historically has been more communicatively oriented. According to him, casework has become more directed towards time management and protocol: "As our communicative practices become colonized, we lose the ability to form our opinions and beliefs through discussion" (Blaug 1995, p. 429).

Although this argument regarding social work is supported by others researchers in the field (e.g., Cooper, 2010; Hayes and Houston 2007; Sinclair, 2005), it is the sectors of health and education that have generated the most evidence of the colonisation thesis resulting from bureaucratic scrutiny. Much of the focus here has been on the damage accountability has done to issues of trust. Brown (2007) refers to the instrumentalising of trust, specifically regarding the transformations taking place in the British NHS. According to him, the bureaucratic drain on medical professionals, "dramatically reduces the time available to sit down with the patient, answer questions and provide comfort and reassurance" (Brown 2007, p. 10). Using Habermas' theoretical base, Brown argues that levels of trust are threatened by the rationalisation of healthcare "through the neglect of the communicative act by which the patient's best interests are articulated, agreed upon, and by which the professional can affirm him/herself as both caring and competent" (Brown 2007, p. 12). 
A range of other Habermas-inspired critiques of the health sector take to task the introduction of consumer accountability and its negative impact on patient/health professional interactions (e.g. Donnelly et al., 2013; Godin et al., 2007; Mikkelsen et al., 2008). Similar arguments can also be found in education, where concerns have been raised over the encroachment of consumerism into the professional-non-professional relationship (see Aper, 2002). Such a view arguably reflects those of a large proportion of education professionals, and their attitudes towards the dysfunctionality of hyper-instrumentalist logic applied to education, particularly via testing ${ }^{\mathrm{i}}$.

The damage done to relations of trust resulting from new bureaucratic methods of governance, is compounded by the effects new bureaucratic modes of regulation have on the moral agency of street-level bureaucrats. This was the focus of Zacka's study When the State Meets the Street: public service and moral agency (2017). Zacka explores the ways in which what he calls the 'moral lives' of street-level bureaucrats - the frontline social and welfare workers, police officers, and educators - are realigned and reconstituted in the face of increased regulatory frameworks. Combining insights from Lipsky and Weber alongside his original ethnographic fieldwork (he worked as a receptionist in an urban antipoverty agency), Zacka argues that frontline workers are faced with 'impossible situations' (2017, p. 200) with competing claims to their authority and expertise weaving their way into procedures, regulations, protocols but also into forms of tacit knowledge and professional practice, altering the DNA of front-line services. This has pathological side-effects which help corrode the moral integrity of public services. Teachers for example become indifferent or hostile to their students in the face of competing demands and what appear as attacks on their professional integrity. When faced with bureaucratic pressures, street-level bureaucrats are effectively forced to continually adopt 
reductive and unsatisfactory conceptions of their own professional responsibilities, 'each by itself pathological in the face of a complex, messy reality'.

Zacka talks of impossible situations as a kind of 'performative self-contradiction' (2017, p. 227), one that street-level bureaucrats find themselves in when attempting to reconcile their own sense of professional identity, and worth in the face of contradictory demands. The impossibility arises when professionals such as teachers, struggle to retain their moral identity and integrity 'while continuing to systematically and consciously perform actions that are contrary to it (pp. 227-228). He summarises it thus:

You cannot expect me, as a teacher, to keep doing what I need to do to meet the accountability requirements. As a teacher, (according to how I understand this term and myself), it is impossible for me to do so. Of course, I, as an individual, could still perform the actions that you require of me. But I would effectively no longer be a teacher in my own eyes. What I cannot do is hold on to the identity and to the actions at the same time (quoted in Zacka, 2017, p. 228).

This breakdown of moral agency at the front-line has significant implications for state legitimacy. The front-line of public services, where state and street-level forms of bureaucracy meet, represents government's human face to ordinary citizens, and is a significant indicator of the state's duty of care and of its moral guardianship. The state's capacity to protect its citizens find its litmus test in this moral integrity. Front-line services are also important from a conceptual point of view as they offer a street-level approach to understanding bureaucracy, governance and democratic life, a ground-up approach that illustrates how fluid and complex 
governance is in the lives of both professional services and those ordinary citizens who avail of them.

Given that the dominant focus across these studies is on the colonising tendency of instrumental rationality, it is worth pausing to consider the alternative theory - colonisation via communicative reason, especially as it has implications for how one understands the perceived benefits of accountability. Although untested and lacking strong empirical support, it could be the case that such an alternative theory could be built off the back of the colonization thesis. Habermas himself recognises this potential in Between Facts and Norms (1996), in which he suggests that communicative reason can also overstep the mark and dominate in areas without recognising its own limitations. He was acutely aware of the "anarchist consequences" (Gregoratto, 2015, p. 539) of his theory of communicative action, of a form of reason that failed to acknowledge societal complexity and institutional reality.

Such an argument could tentatively be applied to the communicative element of much of the accountability agenda and the desire for justification and answerability - i.e., transparency. There is an almost fetish-like search for transparency in public sector governance - a trend visible for example in the health care sector internationally - where there is a great demand for new forms of audit, control, and reporting systems which "reveal and visualise health care processes and outcomes" (Blomgen \& Sahlin, 2007, p. 155). This desire to reveal and make visible process of legitimation and justification may constitute pathological consequences in themselves, of a dysfunctional communicative element in the structures of governance.

\section{Expanding concepts of bureaucracy and accountability}


The application of Habermas' colonization thesis helps us expand our conceptions of bureaucracy and the downsides of accountability, especially when the relation between theory and practice is drawn closer together, as per above. This turn has a number of advantages: it allows for a greater degree of scrutiny of the pathologies of modernization; it updates Weber in relation to for new forms of bureaucratization, and it brings a critique of political economy into the analytical frame. But while this application of Habermas is an important contribution to the theory of public administration, it is an application that comes with strings attached. The theory of lifeworld colonisation is quite abstract and is built on a complex conceptual apparatus of communicative action - its relation to forms of (professional) practice cannot be taken as a given or easily applied to distinct workplace contexts and policy reforms. It is also the case that Habermas deployed the theory to capture pathologies in the context of lifeworld activities, such as damage to forms of cultural reproduction: pathologies of governance were not necessarily in his sights. This is partly because he was more concerned with the ills of capitalist modernisation than the perils of regulatory governance.

As a result, his focus on cultural reproduction never translated into an interest in the lifeworld of professionals working in state bureaucracies. This is a missed opportunity, as this shift in perspective can provide an alternative view of bureaucracy as mediated by professionals - by those who interact with the public and deliver public services. From this perspective, one can take a more detailed look at bureaucratic and regulatory governance as they are practiced at the level of the "street" - as detailed by Lipsky in Street-level bureaucracy. Street-level professionals are in a position to "make policy" through their ability to exercise judgement and use discretion when they engage with the public (as teachers, nurses, social workers, etc). Working at the level of the street provides them with an important mediating function when it 
comes to the demands of state-level bureaucracy, providing them with a priceless autonomy over how they implement policy directives in their interactions with members of the public.

Lipsky positioned this intersubjective dimension - the relations and communications that occur between people - as a key component of the work of street-level bureaucrats. It is also a dimension at the heart of Habermas"s theory of communicative action. The essence of street level bureaucracy is that it requires professionals to "make decisions about other people" (Lipsky 1980, p. 161), a requirement that positions professionals as producers of policy (Hupe \& Hill 2007, p. 280). This conception of policy production at the level of the "street" provides an alternative to more traditional systems-level approaches to government regulation and control. Alongside this, a theory of street-level bureaucracy creates a conceptual space via which to examine how professionals such as nurses manipulate official policy in the context of their relationships with the public - an aspect ignored by Habermas. Although Lipsky was aware that street-level bureaucrats operated within the context of significant external constraints, their position at the level of the street afforded them a position of real influence.

Incorporating the street-level into the analytical framework surrounding bureaucratic governance also has the added value of highlighting the existence of other regulatory mechanisms that act in tandem alongside the overbearing state-economy apparatus. One of these highlighted in the literature is the role of law - again a subject of significant interest for Habermas (Murphy, 2005). Recent decades have seen the spread of a litigation culture in countries such as the US and the UK, with members of the public increasingly seeking recourse to the law to appeal or complain, or to achieve compensation (Allsop \& Jones, 2008). The increasing tendency of people to resort to litigation suggests that recourse to the law is seen as a more immediate form of taking public services to account. Numerous aspects of public-sector 
work have been affected by the spread of a litigation culture, with the health, police and education sectors seeing steady rises in the number of lawsuits (Furedi \& Bristow, 2012).

It could be argued that this increase in forms of legal accountability on the part of the public, could be a function of a broader legitimation crisis, a crisis that pits the state against its own citizens. Whether or not this is the case, it is evident that this development has implications for public sector work. The author's own work examined the prevalence of legal forms of accountability in the public sector and their impact on professional work (Murphy and Skillen, 2018). The evidence indicates that the mechanisms of quality assurance, designed to document and measure quality, can also act as mechanisms of legal exposure for professionals. The findings evidence the conflicting effects of evidential exposure, with the evidential requirements of accountability constituting a double-edged sword: evidence providing a platform for calling individuals and institutions to account, while also opening up professionals to liability exposure. The evidential nature of accountability mechanisms, as Michael Power previously argued, increases exposure to legal risk (Power, 1997).

As a key tool of the regulatory state, accountability tends to magnify legal risk in public sector professions, as evidential exposure uncovers incompetence and lays the blame at unchecked professional discretion and judgement. This form of bureaucracy brings with it a culture of suspicion, and this culture, as well as the strategies of containment it encourages among institutions, is difficult to disengage from once established. The magnification of legal risk compounds this culture, one in which the capacity to cover one's tracks and avoid legal risk become all important. 
Concerns over this form of overregulation, as well as the role of professional discretion, illustrate the importance of incorporating the professional level into our understandings of accountability. They also offer a useful way of addressing limitations in Habermas' conceptual apparatus and the incapacity of the colonization thesis to include the professional sector into the theory of system-level steering. This indicates that the dual methodological approach favoured by Habermas works only in certain scenarios, and needs further refinement to better represent modern forms of political governance. After all, the debate over accountability and its consequences is to a great extent a product of boundary disputes - who gets to make professional decisions, where does judgement and discretion lie and to what extent should it be deployed? Regulatory oversight seeks to discipline and manage professional autonomy but there needs to be a greater understanding of the consequences of this oversight as well as the numerous ways in which policy can be made at the level of the street.

\section{Conclusion}

Bureaucratic forms of regulation have their benefits and it would be unfair to dismiss these offhand in the desire to categorise bureaucracy purely as 'red tape'. This was not the intention of Weber, and the same can be said for Habermas. There are functional elements of bureaucracy that have become indispensable in the modern world, and it is wise to remember that bureaucracy provides an efficient answer to increasing societal complexity via an organisational form "premised on the ethical values of universalism and meritocracy" (Clegg, 2011, p. 206). At the same time, it is important to consider the tensions that exist between bureaucracy and democratic imperatives, and the work of Habermas has helped to illuminate these tensions in a way that does justice to the early work of Weber. His work also points us 
away from the minutae of performance criteria and efficiency savings and towards a broader focus on the question: how do we manage modernity? (Clegg et al, 2011).

That said, Habermas does not have the last word on the pathologies of bureaucracy and accountability, and this paper has endeavored to explore his contribution in the context of others socio-theoretical ideas, in this case street-level bureaucracy. Building conceptual bridges between set of ideas helps to assess the accuracy and value of abstract theory in practical contexts, a process Habermas himself would no doubt agree with. He is after all a master of hybridization, an intellectual strength which is no more evident than in the two volumes of The theory of communicative action. Here he expertly weaved together a complex theory via measured critiques of Durkheim, Weber, Marx and Mead, among others (Murphy, 2017).

Preaching the benefits of hybridization is an important activity when it comes to the theorymethod relationship, as too often researchers approach theories as if they represented the final say on social issues. This form of theoretical fetishism is to be avoided, as the most effective research applications of theory adopt a critical stance, opening theory to critique while combining it with other socio-theoretical concepts. At their best they also aim to 'test' theory against practice: the examples included in this paper, from education, health and social work, illustrate the utility of Habermas to analysis of public sector reform agendas, but also suggest that no one theory (no matter how comprehensive) can manage to explain in full the complexity of changing forms of public policy and professional practice.

\section{References}

Adorno, T., \& Horkheimer. M. (1972). Dialectic of enlightenment. London: Continuum. 
Allsop, J. and Jones, K. (2008). Withering the citizen, managing the consumer: Complaints in healthcare settings. Social Policy and Society, 7(2), 233-243.

Althusser, L. (1971). Lenin and philosophy and other essays. New York: Monthly Review Press.

Aper, J. (2002). Steerage from a distance: Can mandated accountability systems really improve schools? Journal of Educational Thought, 36(1), 7-26.

Barberis, P. (1998). 'The new public management and a new accountability. Public Administration, 76, 451-470.

Bevan, G., \& Hood, C. (2006). What's measured is what matters: Targets and gaming in the English public health care system. Public Administration, 84(3), 517538.

Blaug, R. (1995). Distortion of the face-to-face: Communicative reason and social work practice. British Journal of Social Work, 25, 423-439.

Blomgen. M. \& Sahlin, K. (2007). Quests for transparency: Signs of a new institutional era in the health care field. In Christenensen, T. and Laegeid, P. (eds), Transcending new public management: the transformation of public sector relations, pp. 155-178. Surrey: Ashgate. 
Broadbent, J. \& Laughlin, R. (1998). Resisting the 'new public management': Absorption and absorbing groups in schools and GP practices in the UK. Accounting Auditing and Accountability Journal, 11(4), 403-435.

Brown, P. (2007). Trust in the new NHS: Instrumental versus communicative action. Sociology of Health and Illness, 30(3), 1-15.

Christenensen, T., Lie, A. \& Laegeid, P. (2007). Still fragmented government or reassertion of the centre? In Christenensen, T. and Laegeid, P. (eds), Transcending new public management: the transformation of public sector relations, pp. 17-42. Surrey: Ashgate.

Clegg, S. (2011) Under reconstruction: Modern bureaucracies. In Clegg, S., Harris, M. and H Höpfl (eds), Managing modernity: Beyond bureaucracy? pp. 202-229. Oxford: Oxford University Press.

Cooper, B. (2010 Educating social workers for lifeworld and system. In Murphy, M and T. Fleming (eds), Habermas, Critical theory and education. New York: Routledge.

De Bruijn, J. A., \& Van Helden, G. J. (2006). A plea for dialogue driven performance-based management systems: Evidence from the Dutch public sector. Financial Accountability \& Management, 22(4), 405423.

Diefenbach, T. (2009). New public management in public sector organizations: The dark sides of managerialistic “enlightenment”. Public Administration, 87(4), 892-909. 
Dillard, J. F., \& Ruchala, L. (2005). The rules are no game: From instrumental rationality to administrative evil. Accounting, Auditing \& Accountability Journal, 18(5), 608630.

Donnelly, S., Carter-Anand, J., Cahill, S., Gilligan, R., Mehigan, B. \& D. O’Neill (2013) Multiprofessional views on older patients' participation in care planning meetings in a hospital context. Practice: Social Work in Action, 25(2), 121-138.

Franco-Santos, M., Lucianetti, L., \& Bourne, M. (2012). Contemporary performance measurement systems: A review of their consequences and a framework for research. Management Accounting Research, 23(1), 79119.

Furedi, F. \& Bristow, J. (2012). The social cost of litigation. London: Centre for Policy Studies.

Glaeser, E. \& Shleifer, A. (2003). The rise of the regulatory state. Journal of Economic Literature, XLI, 401-425.

Godin, P., Davies, J., Heyman, B., Reynolds, L., Simpson, A. \& M. Floyd (2007). Opening communicative space: A Habermasian understanding of a user-led participatory research project. The Journal of Forensic Psychiatry \& Psychology, 18(4), 452-469.

Gregoratto, F. (2015). Political power and its pathologies: An attempt to reconsider Habermas' critical theory of democracy. Constellations, 22(4), 533-542.

Habermas, J. (1976). Legitimation crisis. Oxford: Blackwell Press. 
Habermas, J. (1984). The theory of communicative action, vol 1: Reason and the rationalization of society. Boston: Beacon Press.

Habermas, J. (1987). The theory of communicative action, volume 2: Lifeworld and system: A Critique of Functionalist Reason. Boston: Beacon Press

Habermas, J. (1996). Between facts and norms. Cambridge, MA: MIT Press.

Hayes, D. \& Houston, S. (2007). "Lifeworld", "system" and family group conferences: Habermas's contribution to discourse in child protection. British Journal of Social Work, 37(6), 987-1006.

Hood, C. (2011). The blame game: Spin, bureaucracy, and self-preservation in government. Princton, NJ: Princeton University Press.

Houston, S., Magill, T., McCollum, M. \& Spratt, T. (2001). Developing creative solutions to the problems of children and their families: Communicative reason and the use of forum theatre. Child and Family Social Work, 6, 285-293.

Hudon, P. \& Rouillard, C. (2015). Critical management studies and public administration: Reinterpreting democratic governance using critical theory and poststructuralism. Canadian Public Administration, 58(4), 527-548,

Hupe, P. and Hill, M. (2007). Street level bureaucracy and public accountability. Public Administration, 85(2): 279-299. 
Jessop, B. (2015). The state: Past, present, future. Cambridge: Polity Press.

Lipsky, M. (1980). Street-level bureaucracy: Dilemmas of the individual in public services. New York: Russell Sage Foundation.

Majone, G. (1997). From the positive to the regulatory state: Causes and consequences of changes in the mode of governance. Journal of Public Policy, 17, pp 139-167.

Marx, K. (1959). Economic and philosophic manuscripts of 1844. Moscow: Progress Publishers.

Meier. K. \& O’Toole, L. (2006). Bureaucracy in a modern state: A governance perspective. Baltimore: John Hopkins University Press.

Mikkelsen, T., Soendergaard, J,. Jensen, A. \& F Olesen (2008). Cancer surviving patients' rehabilitation - understanding failure through application of theoretical perspectives from Habermas. BMC Health Services Research, 8: 1-22.

Müller-Doohm, S. (2010). Nation state, capitalism, democracy: Philosophical and political motives in the thought of Jürgen Habermas. European Journal of Social Theory, 13(4) 443457.

Moran. M. (2007) The British regulatory state: High modernism and hyper-innovation. Oxford: Oxford University Press 
Murphy, M. (2005). Between facts, norms and a post-national constellation: Habermas, law and European social policy. Journal of European Public Policy, 12(1), 143-156.

Murphy, M. (2010). Forms of rationality and public sector reform: Habermas and education in the context of social policy. In M. Murphy \& T. Fleming (Eds) Habermas, critical theory and education, pp. 78-93. New York: Routledge.

Murphy, M. (2017). Introduction: Putting Habermas to work in social research. In M. Murphy (ed.), Habermas and social research: Between theory and method, pp. 1-18. Oxon: Routledge.

Murphy, M. \& Skillen, P. (2015). The politics of time on the front line: street level bureaucracy, professional judgement and public accountability. International Journal of Public Administration, 38(9), 632-641

Murphy, M. \& Skillen, P. (2018). Exposure to the law: Accountability and its impact on street level bureaucracy. Social Policy and Society, 17(1), 35-46.

Myers, M. \& Young, L. (1997). Hidden agendas, power and managerial assumptions in information Systems development: An ethnographic study. Information Technology and People, 10(3), 224-240.

Offe, C. (1984). Contradictions of the Welfare State. London: Hutchinson. 
Papadopoulos, Y. (2010). Accountability and multi-level governance: More accountability, less democracy? West European Politics, 33(5), 1030-49.

Prychitko, D. (1990). The welfare state: What is left? Critical Review, 4(4), 619-632.

Power, M. (1997). Audit cultures: Rituals of verification. Oxford: Oxford University Press.

Roberts, J. (2009). No one is perfect: The limits of transparency and an ethic for "intelligent" accountability. Accounting, Organizations \& Society, 34(8), 957970.

Schwier, R. (2012). The corrosive influence of competition, growth, and accountability on institutions of higher education. Journal of Computing in Higher Education, 24, 96-103.

Shore, C. (2008). Audit culture and illiberal governance: Universities and the politics of accountability. Anthropological Theory, 8(3), 278-298.

Sinclair, T, (2005). Mad, bad or sad? Ideology, distorted communication and child abuse prevention. Journal of Sociology, 41(3): 227-246.

Steijn, B. \& van der Voet, J. (2017). Relational job characteristics and job satisfaction of public sector employees: When prosocial motivation and red tape collide. Public Administration, 117.

Travers, M. (2007). The new bureaucracy: Quality assurance and its critics. Bristol: Policy Press. 
Visser, M. (2016). Management control, accountability, and learning in public sector organizations: A critical analysis. Governance and Performance in Public and Non-Profit Organizations. Studies in Public and Non-Profit Governance, 5, 7593.

Weber, M. (1954). On law in economy and society. New York: Free Press.

Weber, M. (1958). Religious rejections of the world and their directions. In From Max Weber, ed. H. Gerth and C.W. Mills, pp. 323-59. London: Kegan Paul.

Weber, M. (1968). Economy and society. Eds G. Roth and C. Wittich. New York: Bedminster Press.

Weber, M. (1974). Max Weber on universities: The power of the state and the dignity of the academic calling in Imperial Germany. Chicago: University of Chicago Press.

Weber, M. (2001). The protestant ethic and the spirit of capitalism. London: Routledge.

Weber, M. (2004). Science as a vocation. In Vocation lectures, ed. D. Owen and T. Strong, 32-94. Indianapolis, IN: Hackett Publishing.

West, A. (2010) High stakes testing, accountability, incentives and consequences in English schools. Policy \& Politics, 38(1), 23-39. 
White, S. (2016). Continental and analytic lenses in relation to the communicative action paradigm: Reconstructive thoughts. European Journal of Political Theory, 15(2) 189-204.

Zacka, B (2017). When the State Meets the Street: Public Service and Moral Agency. Cambridge: Harvard University Press

\footnotetext{
i There is growing evidence in the United States that the pressures associated with educational testing are leading to cases of professional malpractice, particularly in the form of exam cheating on the part of staff. See for instance: https://www.washingtonpost.com/local/education/eight-atlanta-educators-in-test-cheating-casesentenced-to-prison/2015/04/14/08a9d26e-e2bc-11e4-b510-

962 fcfabc310 story.html?utm term=.b31a00325943.

And also: http://ionathanpelto.com/2015/08/30/did-the-achievement-first-charter-school-chain-cheat-onthe-connecticut-sbac-tests/
} 